\title{
Gendered EFL Classroom Interaction-A Case Study in a Senior Middle School in China*
}

\author{
Wenhua $\mathrm{Hu}$ \\ Dalian University of Technology, Dalian, China \\ Email: hwh68@yahoo.cn
}

\begin{abstract}
In this paper, I present the findings of a case study I conducted in a senior high school in China with 47 students and their teacher. An ethnographic classroom observation approach was employed in my study. The findings showed that differential teacher treatment by gender did exist. Educators at all levels need to be aware of the fact that learners may respond to similar educational experiences in different ways. Then we can work toward a balance between providing both male learners and female learners with all types of educational experiences and helping both males and females acquire the skills necessary to benefit maximally from various types of learning environment.
\end{abstract}

Index Terms — classroom interaction, EFL, gender differences

\section{INTRODUCTION}

One presumed goal of education is to maximize each chance of academic success and to prepare youth for more schooling or for participating in the occupational structure. Yet there is evidence that the outcomes of education are not the same for one another in certain subject areas and pursuer with quite different careers once they have completed their schooling. The stability and persistence of gender differences have given rise to a concern about sex equity in the classroom. It may be that the differences in attainment found between males and females are rooted in gender-based contrasts in international experiences in classrooms. A voluminous literature covers the general subject of male-female differences, and a sizable body of research exists as well on patterns of interaction in classrooms.

Studies that compare the classroom interaction of boys and girls are relatively scarce, but a few of the studies report clear-cut gender-related differences. Many contemporary theorists use the term 'gender' for the behavioral differences between males and females. In a Chinese context, gender issue is not as popular a topic as in western countries. But it still exists. At the beginning of the 20th century, girls did not have the same right to go to school as boys did. There was a popular saying in China at that time, "The virtuous woman is the unlearned woman." It still took quite some time for people to accept this idea. But the idea that the ultimate goal for women is to marry a good man is still favored by some people in the countryside and they do not allow their daughters to enter school. The situation is much better in cities in China nowadays since there is a law that requires 9 years of education. This is compulsory for all children and the whole economic situation is growing. China is not a religious country and so far as I know there are no single -sex primary schools and secondary schools, though occasionally there are some vocational schools for girls, where all the subjects taught are considered to be female subjects. In my home city, there is only one school for girls only, and all the other schools are mixed-sex.

As far as I know, there is no study conducted on gender and classroom interaction in China at the secondary level. I came from the Chinese educational background. I could think of some quite interesting things related to gender in my lectures during my sixteen years' study experience in china. I am very interested in having a close look at this particular issue- gender and classroom interaction. My major subject in university was English education, which has caused my interest to be set in English classroom.

My research questions:

Does the teacher treat boys and girls differently?

Do boys and girls behave differently?

\section{LITERATURE REVIEW}

Before we get down to the gender and classroom interaction issue, I would like to present a brief review of education in China.

Education is considered to be a very crucial condition for accomplishing four modernizations. According to Rai (1994), the expansion of female education in China occurred mainly in two periods, from 1950 to 1958, and from 1966 to 1976. These periods mark the beginning of the communist rule in China and the Cultural Revolution. After the Cultural Revolution in China, education was emphasized more than ever. More and more schools have been opened since that time. A compulsory education law was promulgated in 1958 to eradicate illiteracy. With the success of the

* The publication of this paper is supported by the "the fundamental Research Funds for the Central Universities"(DUT10RW413) 
one child policy in 1978 in urban areas, the education of girls has increased and the situation is much better for girls now. The school I collected data from has 745 female students and 657 male students enrolled. Though girls have the same right as boys to be educated nowadays, do they treat equally as boys in the school? The literature of gender and classroom interaction can barely be found in China. I hope that my study could help to fill this gap.

Bearing the interaction mode of the teacher and the students in mind, the studies of gender issues in classroom interaction seem to have three categories. 1. Can gender differences be detected in the patterning of students' responses? 2. If so, can the differences be related back to teacher initiation? 3. Does teacher feedback vary according to gender? (Howe, 2002)

Three studies on the secondary school level have been reported; all deal with sex differences in students' experiences in mathematics classes. Becker (1981) reported interactions patterns in 10 high school geometry classes in which Becker observed that the teachers were more likely to call on or otherwise initiate interactions with boys than with girls. Much of their behavior suggested that the boys were expected to learn geometry but the girls were not.

Stallings (1979) observed in high school algebra and geometry classes and found similar but weaker patterns to those reported by Becker. Though few of the differences are significant, the trend is rather clear. Men are spoken to more often than are women. Men ask more questions and teachers asked men more questions. Women volunteer answers as often as do men but the men are called upon to respond more frequently than are women. Men receive a little more individual instruction and social interactions. Acknowledgement, praise, encouragement, and corrective feedback are given slightly more frequently to men than to women. The only variable that occurs more frequently with women is positive interactions. Teachers smile or laugh more often with women students than they do with men.

The weaker pattern of differences may be due to the fact that Stallings observed in these classes less frequently than Becker did. Also, questionnaire responses from the teachers indicated that they felt that male and female students were equally good at mathematics and did not differ in spatial ability. These response patterns are unusual and suggest that these teachers may have been less traditional in their sex-role orientation than most teachers.

Parson et al. (1980) observed 10 sessions in each of 18 mathematics classes. Their observation indicated that girls received less criticism than boys and, specifically, less work-related criticism and less criticism of the quality plus the form of their work. Almost all wok-related praise and criticism were directed at the intellectual quality of the work rather than its form or other aspects unrelated to correctness. Thus, there was no teacher tendency to praise boys more than girls for good intellectual quality of work, nor to criticize girls more than boys for work of poor intellectual quality of work. Nor did teachers interact more often with boys, ask them different types of questions, or provide different types of feedback to their responses.

It is difficult to know how to interpret these confusing secondary school results, particularly the contrast between the Becker (1981) findings and those of Parsons et al. (1980). Both studies involved 10 observations in each of the classroom, so the sex differences are probably quite reliable. Differences in the types of teachers included in the studies or in the geographical areas in which the data were collected may explain some of the contrasting findings. The most likely explanation, however, is grade level. Most of the classes studies by Parson et al. were junior high or ninth-grade math courses taken by all of the students, whereas all 10 classes studied by Becker were geometry courses taken only by the brighter an more mathematics-oriented students. Dramatic sex differences of the kind reported by Becker, if frequent at all, may be frequent only in secondary level courses of this type. In this connection, it should be noted that Stallings' (1979) results, which generally fell between those of Becker and those of Parson et al., were collected in lower level algebra and geometry classes that fell between the other two samples in terms of the kinds of students represented and their level of progress in mathematics.

The data continue to indicate that male and female teachers are much more similar than different, both in their general approaches to instruction and in their interactions with male and female students. Teachers do not systematically discriminate against students of the opposite sex.

Most of the studies mentioned above were conducted in science classes. Little literature about gender and foreign language classroom interaction can be found. The result might be generalized into the language classroom, but it cannot be guaranteed. Furthermore, to my knowledge, there is no study conducted in Mainland China about gender and English classroom interaction at secondary level.

\section{DATA COLLECTION}

\section{A. The Setting}

1. The choice of Teacher and Student

My research interests and focus are on the relationship between gender and classroom interaction. The best way that I can think of to investigate this is to sit in a classroom to observe what happens there. I am particularly interested in what happens in the language classroom since I am working as a university English teacher. The advantage of choosing the school I gathered my data from is that one of my good friends in the university is an English teacher in that school. After I came to Dalian University of Technology to work as a lecturer there, we still kept in touch. So when she knew I was worried about my data collection, she offered to help me to access her school. "If you like, you can observe my classes. You are welcome!" she told me once when we chatted online. I was very happy about this since if I could enter 
her school and observe her class, it would be a very pleasant experience to work with a good friend. Following that, she gradually introduced her school to me. The school is a secondary school in which all the classes are mixed -sex with approximately 50 students in each class. It is located in my hometown of Dalian, China. There are different quality senior high schools in the city. The collection of the students is according to the marks the students receive in the entrance examination in each June. The better marks they receive, the better school they will enter. Their school is not amongst the best quality ones. But neither are they the lowest ones since there are still many vocational schools behind it. Since it is not the good quality school, the academic ability amongst students varies a lot, but in general, most of them are at a low academic level. My friend in that school told me that several students in her class could not even remember the 26 English letters. But the requirement for them is to have at least 2000 words of vocabulary. There are 16 teachers in total to teacher English in the school, but none of them is male. I did not have a chance to find out the difference between male and female teachers in the sense of interacting with their students.

Brophy and Good (1974) located only a few studies comparing male with female teachers in their treatment of male versus female students. These studies all agreed, however in findings that classes taught by male teachers show the same kinds of student sex differences as classes taught by female teachers. That is, attitude assessments showed that male teachers preferred conforming and obedient students to independent and assertive students.

Therefore, if I get opportunities to do further research on gender and classroom interaction in Chinese context, I will include study on male teachers in my project to see whether Brophy and Good's conclusion is feasible or not in China.

2. The classroom teacher

At the beginning, my friend intended to help me to enter the class of an experienced teacher because she felt that the teacher is quite skillful in teaching and controlling the class. I did not reject her offer since I also wanted to have more chances to observe classes. The teacher agreed to take me to her class, but one problem was that she refused to use the tape-recorder. She told me that she would feel very nervous about it and the students in her class were very curious .On second thoughts, I decided to focus on my friend's class only. So the classroom teacher in this research is my friend. She is in her thirties. She had been working as a teacher in that school for almost eight years when the observation took place. She is the kind of person who always shows her consideration to others.

3. The students

There are 47 students in the English class in total. But they are from two different organizational classes named Class A and Class B. 15 girls and 8 boys are from Class A and 10 girls and 14 boys are from Class B. the main data I collected are from the mixed class of Class A and Class B. but I still transcribed one lecture of those 15 girls and 8 boys in Class A, which is quite interesting. Their average age is 15 . They came to the school for about 8 months at the time I collected the data. The English class is a compulsory course for all of them.

4. The Classroom Arrangement

The Classroom for the two mixed classes is big. The desks for the students are in 8 lines and 6 rows. Each two lines were put together so that the students are divided into 4 groups. The students are not free to choose where to sit, but the teacher will manage it. The classroom for the small class is rather small with 8 lines and 4 rows. There are 4 lines together in the middle of the classroom and 2 lines are together at both right and left of the classroom. Interestingly, all girls choose to sit together and all boys do so.

\section{B. The Methodology}

\section{Classroom Observation and field notes}

Since my research questions are related to classroom interaction, classroom observation is a quite important methodology for my research. I attend the English class as an observer. In the first class, the teacher introduced me to the students. But the introduction was quite simple. She just told the students that I need some data for a research project. The teacher let me sit in the front corner of the classroom from which I could have a good view to see what happened and students' face expressions. I was a bit worried about the place I sat since I thought even though it was a corner; it was still in the front of the classroom. I was afraid that my stay would influence their performance. But the teacher told me, the students were quite used to strangers coming into their classroom since the senior high school specialized their English class and many outside researchers and teachers would come to visit. For the time being, I could see that what the teacher told me was quite true. In the first class, some of the students would glance at me, but it seemed that they took me as a member of their classroom after they saw me the second and the following classes, I took a notebook with me every time so that I could write down what I could see in a particular moment to supply what might be missed in the recorded data.

2. Tape Recording and Transcription

Though the video data camera could catch more things than a tape-recorder does, I still decided to tape-record the classes. If I use a video camera, in order to catch as many things as possible, I need to place it on a very good position, which I think should be in the front of the classroom. But it is obvious that it would definitely seek the students' attention and that will influence the reliability of the data.

I recorded 14 lectures in total. Two of them on one tape are missing. One of them contains barely any students' talk. I intended to focus on 4 lectures only at first, but after I listened to the tape, I found that my friend led the classroom talk; students did not talk that much in each lecture. So I felt the urge to add two more lectures. Though it is still limited, due to the time-limitation, I could not focus on and transcribe more lectures. The relevant parts, which I analyzed in my 
paper were translated in to English. In the transcription, I avoided using the real name of the students. So all the names in the transcription are edited ones.

3. Informal Interview

I did not interview the teacher and the students formally because of the time and some other reasons. But during some break times, I chatted with them and noted down their ideas and opinions, which I thought interesting and relevant to my research. This informal data shed light on what happened in the classroom.

4. Test Results

My friend provided me with test results for different subjects with the permission of other teachers of those two lectures. The reason for me to gather the result forms is to examine whether there is a relationship between the students' performance in the class and their achievement. Since when I was a student at secondary level, I was not willing to talk in class, if it was the subject that I was not good at.

\section{QuANTITATIVE ANALYSIS}

\section{A. Teacher's Talk}

I analyzed two kinds of teacher talk in this chapter. One is teacher's solicits and the other is teacher's feedback.

1. Teacher's Solicits

A solicit, according to the unpublished PhD thesis of Jane Sunderland (1996) is normally a teacher-student (but not teacher -whole class) or student -teacher utterance which requires and/ or results in a verbal response or which results in or requires a behavioral one from the student or teacher respectively very soon after the uttering of the solicit.

I analyzed two kinds of teacher's solicit together in this section: questions assigned and turns allocated to boys/girls.

A question assigned is like "Wang, what does pioneer mean?"

A turn allocated is like "who can recite it again? Tom."

After I observed several lectures I realized that the teacher did not nominate individual students to stand up to answer questions very often. Her own presentation took a large amount of time. Alternatively, she would ask a question to the whole class, and anyone could answer it without raising his or her hand, just by calling out. I asked the teacher whether she was aware of this; and she said yes and complained that there were too many things to present in one lecture. It would be time-consuming if the student she asked to answer a question did not know the answer or found it difficult to give a correct answer in one try. However, she did sometimes address individual girls or boys. The number of boys and girls is not equal in this class (22 boys and 25 girls). It is not enough to calculate the total number of questions and turns. So I also employed 'boy average' and 'girl average', which would enable me to look at whether the nomination of the teacher is in a similar proportion to 'boy average' and 'girl average'. (see Table 4a)

TABLE 4A:

QUESTIONS ASSIGNED AND TURNS ALLOCATED TO BOYS/GIRLS

\begin{tabular}{|l|l|l|l|l|}
\hline \multirow{2}{*}{ Lectures recorded } & Boys & \multicolumn{2}{l|}{ Girls } \\
\cline { 2 - 5 } & Total & 'boy average' & Total & 'girl average' \\
\hline Lecture 1 & 3 & 0.14 & 7 & 0.28 \\
\hline Lecture 2 & 6 & 0.27 & 8 & 0.32 \\
\hline Lecture 3 & 6 & 0.27 & 12 & 0.48 \\
\hline Lecture 4 & 4 & 0.18 & 4 & 0.16 \\
\hline Lecture 5 & 2 & 0.09 & 2 & 0.08 \\
\hline Lecture 6 & 3 & 0.14 & 5 & 0.20 \\
\hline Total & 24 & 1.09 & 38 & 1.52 \\
\hline
\end{tabular}

Though the number of the questions and turns are small, except in lecture 4 and lecture 5 (the numbers are the same), we can see that the teacher asked more questions and allocated more turns to the girls (Lecture 1: 7 to 3; Lecture 2: 8 to 6; Lecture 3: 12 to 6; Lecture 6: 5 to 3) than to the boys in general (38 to 24). The average girl also got slightly more than the average boy did (1.52 to 1.09), though because of the limited number of questions and turns, it did not show a great difference.

2. Teacher's Feedback

I categorized the feedback provided by the teacher into two types: positive feedback and negative feedback. Positive feedback implies the teacher's partial or full acceptance of the answer, while negative feedback implies that the answer is not a correct one according to the teacher or the teacher needs the answer to be improved. The degree of feedback can also vary. Feedback like "very good. You did a very good job" is more positive than a simple "yeah" or "okay". A teacher might thus provide positive feedback to two students, but the feedback to one student might be more positive than the one she provides to the other students. However, I categorized both as 'positive'. (See Table 4b) 
TABLE 4B:

POSITIVE /NEGATIVE FEEDBACK TO BOYS/GIRLS (AS INDIVIDUALS)

\begin{tabular}{|c|c|c|c|c|c|c|c|c|}
\hline \multirow{3}{*}{$\begin{array}{l}\text { Lecture } \\
\text { recorded }\end{array}$} & \multicolumn{4}{|c|}{ Positive } & \multicolumn{4}{|c|}{ Negative } \\
\hline & \multicolumn{2}{|c|}{ Boys } & \multicolumn{2}{|c|}{ Girls } & \multicolumn{2}{|c|}{ Boys } & \multicolumn{2}{|c|}{ Girls } \\
\hline & Tot. & boy average & Tot. & girl average & Tot. & boy average & Tot. & girl average \\
\hline Lecture1 & 3 & 0.14 & 12 & 0.48 & 1 & 0.05 & 3 & 0.12 \\
\hline Lecture2 & 1 & 0.05 & 2 & 0.08 & 1 & 0.05 & 9 & 0.36 \\
\hline Lecture 3 & 8 & 0.36 & 12 & 0.48 & 1 & 0.05 & 2 & 0.08 \\
\hline Lecture4 & 6 & 0.27 & 4 & 0.16 & 5 & 0.23 & 4 & 0.16 \\
\hline Lecture5 & 1 & 0.05 & 2 & 0.08 & 1 & 0.05 & 2 & 0.08 \\
\hline Lecture 6 & 5 & 0.23 & 8 & 0.32 & 1 & 0.05 & 3 & 0.12 \\
\hline Total & 24 & 1.09 & 40 & 1.6 & 10 & 0.45 & 23 & 0.92 \\
\hline
\end{tabular}

Table $4 \mathrm{~b}$ shows the number of cases of positive and negative feedback given to the boys and the girls by the teacher. Girls got both more positive and negative feedback than boys did (40 to 24; 23 to 10). The 'girl average' also got more positive and negative feedback than the boys did (1.6 to 1.09; 0.92 t o 0.45). Cases of positive feedback for both boys and girls are more numerous than the cases of negative feedback they received (24 to $10 ; 40$ to 23 ). However, the positive feedback (as a percentage of whole feedback) for boys is higher than that for girls (70.6\% to 63.5\%). It seems that though the boys got less feedback, they were treated more encouragingly.

As we will see from Table 4c, the girls in this class were quite active in responding to the teacher's open questions, i.e. when the teacher herself did not nominate a particular boy or girl to answer. After such questions, she would wait for the answer to come from anyone in the class. During the time I stayed with them, I could tell that most of the boys were not active in responding to the teacher's questions. We can infer that because the boys answered fewer questions, they got less of both positive and negative feedback than did the girls. But because of this, the teacher may also have encouraged them by giving positive feedback.

\section{B. Students' Talk}

Two aspects of student talk were analyzed in this chapter: response to the teacher's open questions and questions asked by boys/girls to the teacher.

1. Responses

TABLE 4C

RESPONSES TO THE TEACHER'S QUESTIONS

\begin{tabular}{|l|l|l|l|l|}
\hline \multirow{2}{*}{ Lecture recorded } & Boys & Girls & Girl Average \\
\cline { 2 - 5 } & Tot. & Boy Average & Tot. & 1.36 \\
\hline Lecture 1 & 8 & 0.36 & 34 & 0.40 \\
\hline Lecture 2 & 2 & 0.09 & 10 & 0.80 \\
\hline Lecture 3 & 3 & 0.14 & 20 & 1.76 \\
\hline Lecture 4 & 24 & 1.09 & 44 & 1.76 \\
\hline Lecture 5 & 12 & 0.55 & 44 & 1.08 \\
\hline Lecture 6 & 11 & 0.50 & 27 & 7.16 \\
\hline Total & 60 & 2.73 & 179 & \\
\hline
\end{tabular}

Table 4c shows that girls were more active than boys in answering the teacher's open questions (179t o69). In this English class, the girls liked calling out to respond to the teacher. The 'average girl' responded to the teacher three times more than the 'average boy' did (7.16 to 2.73). The result is similar to the one in the findings of Jane Sunderland's Ph.D thesis (1996): the girls, on average, respond to more of the teacher's academic and non-academic solicits than do the boys. I listened to the tape several times, and though I could not always tell which voice came from which particular girl or boy, I still could tell most of the time whether it was a girl or a boy.

2. Questions

I divided the questions asked by the students into two categories. One type is academic question and the other type is non-academic questions.

By saying that a question is academic, I mean that the question asked is related to lecture content, while a nonacademic question is about lecture procedure or anything else not related to the lecture content. (see Table 4d)

TABLE 4D

QUESTIONS ASKED BY BOYS/GIRLS TO THE TEACHER

\begin{tabular}{|c|c|c|c|c|c|c|c|c|}
\hline \multirow{3}{*}{$\begin{array}{l}\text { Lecture } \\
\text { recorded }\end{array}$} & \multicolumn{4}{|c|}{ Boys } & \multicolumn{4}{|c|}{ Girls } \\
\hline & \multicolumn{2}{|c|}{ Academic } & \multicolumn{2}{|c|}{ Non-Academic } & \multicolumn{2}{|c|}{ Academic } & \multicolumn{2}{|c|}{ Non-Academic } \\
\hline & Tot. & Boy Average & Tot & Boy Average & Tot & Girl Average & Tot & Girl Average \\
\hline Lecture1 & 0 & 0 & 0 & 0 & 0 & 0 & 2 & 0.08 \\
\hline Lecture2 & 1 & 0.05 & 6 & 0.27 & 0 & 0 & 1 & 0.04 \\
\hline Lecture3 & 0 & 0 & 2 & 0.09 & 4 & 0.16 & 1 & 0.04 \\
\hline Lecture4 & 5 & 0.23 & 7 & 0.32 & 9 & 0.36 & 3 & 0.12 \\
\hline Lecture5 & 2 & 0.09 & 6 & 0.27 & 1 & 0.04 & 0 & 0 \\
\hline Lecture6 & 2 & 0.09 & 0 & 0 & 2 & 0.08 & 0 & 0 \\
\hline Total & 10 & 0.45 & 19 & 0.86 & 16 & 0.67 & 7 & 0.28 \\
\hline
\end{tabular}


We can see from Table $4 \mathrm{~d}$ that the number of academic questions asked by the girls is higher than the number asked by boys. (16 to10), while the number of non-academic questions the girl asked is lower than the number asked by boys (7to 19) that is to say, the girls asked more academic questions, while the boys asked more non-academic questions. The boys asked more questions in total (academic and non-academic) than girls did (29 to 23). But of the questions asked by the boys, $65.5 \%$ are non-academic ones. The composition of the girls' questions is $69.6 \%$.academic questions and $30.4 \%$ non-academic ones. In general, the students did not ask many questions.

I chatted with two girls and three boys during the break. I wanted to know why they did not ask many questions to the teacher. I was impressed by two of their explanations. One girl told me that she did have questions sometimes, but she was afraid that her questions were too simple to ask and that the teacher and her classmates would laugh at her. One boy laughed and said that he had many questions, but if he asked the teacher, she would know he was absent-minded.

The boys in the class sometimes asked non-academic questions to distract or draw the teacher's attention. I also saw that after class, the boys were more likely to joke with or tease the teacher, whilst most of the girls remained polite and formal after class.

Summary: the quantitative findings have not been analyzed for evidence of statistically significant differential teacher treatment of male and female students or of differential treatment by gendered student behavior. However, the girls got more questions from the teacher and were assigned more turns. They also answered more questions, (The difference is more marked than the other three), and as a consequence received more feedback from the teacher, both positive and negative. Thus we get the picture that the girls were more active in this class. However, the percentage of positive feedback in relation to all feedback was lower for the girls than the boys.

\section{Qualitative Analysis}

\section{A. Turn Given to Boys}

As I showed in part IV, the teacher assigned more turns to the girls and the girls called out more often than the boys. But when both boys and girls raised their hands, then the turn would undoubtedly be allocated to a boy.

Extract 1:

1. T: Ok, good. Class Six? Yah, please Zhou Ming!

[A girl sat next to Zhou Ming raised her hand as well. But the teacher called Zhou Ming immediately when she saw him raising his hand. The students clapped for Zhou Ming after he finishing reciting]

2. T: Yeah, good. Really good! Ok, how about Class Five? Class Five? No one?

Gx1: Yes. [Gx1 said happily]

3. T: Class Five. No one!

Gx1: Yes. [Gx1 said firmly again]

Bx1: No. Of course.

[A boy from Class Five claimed that they had a student to recite. However, he did not raise his hand. Rather he grasped the hand of a girl next to him. The girl smiled and did not refuse.]

4. T: Really? Ok, Qu Xiaoyan. [Qu Xiaoyan started to recite]

5. T: Ok, good. Now. Class Six?

[The teacher saw that the same girl raised her hand, but she did not call her immediately as if she wanted to wait for more students to raise their hand. B2 raised his hand.]

6. T: Ok Yang Mingliang.

[The teacher was quite surprised to see the boy raising his hand (he was one of the boys whom the teacher poked to wake them up) and called his mane happily without thinking. The girl who raised her hand was disappointed.]

[Yang thanked his classmates for support by putting his two hands together to make a traditional "thank you" gesture. Then he started to recite. The teacher listened quite carefully. The students were excited. Several girls cheered for him after he finished.]

Gs: Wonderful!

7. T: Ok, great. Yang, you really, really surprise me. Now, who can, Class Five, Zhang Jie.

One girl thus kept raising her hand. The teacher, however, was so pleased to see the boys' raise their hands; she did not give the girl a turn and finally, the girl lost interest in raising her hand.

If you sat in the classroom, you could get an impression that the boys in general (not all the boys) did not actively respond to the teacher's academic solicits, while girls in general were more active than the boys in responding to he teacher. The quantitative analysis of responses to teacher's open questions can show this (Girls called out 179 times in total, while the boys called out 60 times). The teacher would tell you similarly. However, I could see that the girl who was bidding for the turn twice ( $\mathrm{T}$ 1: first try; $\mathrm{T}$ 5: second try) raised her hand when the teacher asked for volunteers, though she was not as active as the two girls who stood up to recite the text at the beginning. I attend 16 lectures, so I can remember her because she raised her hand relatively often. (I say relatively since the class was teacher -led on the whole.) The teacher did not seem surprised to see her raise her hand. But she really did seem surprised to see Zhou Ming (the first boy volunteer) raise his hand and gave the turn to Zhou Ming directly. The girl tried for the second time 
when the turn for her class came again. But, sadly, the boy who raised his hand later than her grabbed her chance! I could see her disappointed face and she did not bid for a turn in the activity again in that lecture. I asked the teacher after class and she confirmed that she saw the girl raise her hand twice. However, she told me that she was surprised to see the two boys raise their hands. She further explained that she also felt that the boys were impatient and if she did not give them a turn, it was quite likely that they would chatter away or do other things. But things would be a bit different if she paid attention to them and let them 'show off'. "I think I could encourage them by doing so", she added.

\section{B. How Were the Boys' Attention and Interest Attracted by The Teacher?}

The quantitative findings seem to show that girls were more active in the class. But I found from the data that the boys were active in some particular way. The teacher attracted and retained their attention and interest by; for example, initiating competitive activities or illustrating relevant interesting points of the text, though to attract the boys' attention in particular was not the main purpose as the teacher told me after class. What happened in the class nevertheless showed the effects of these initiations.

1. Teacher -Initiated Competitive Activities

Extract 2:

The following episode happened at the beginning of a lecture. The teacher intended to check the students' homework, which was to recite the text.

1. T: Ok, so remember your homework yesterday?

S: Yeah.

2. T: Yah, recite, Class Five, the first one, right? Class Six, second one, second one. Ok, who like to be the first one?

3. T: Ok, Sun Mo.

[Sun Mo started to recite]

4. T: Um ah. Ok, good. Now how about Class Six? Who like to?

[Yu Shuang raised her hand]

5. T: Yes, (Yu Shuang)

[Yu Shuang started to recite]

[While the two girls were reciting, one girl dozed off there and used the hand to raise her head. Three boys put their heads down on their desks. The teacher walked around and poked the three boys to wake them up.]

6. T: So that's all. Ok, so next time let's do that this way, right? One is from the Class Five; the other is from Class Six. So at last let's see which side will win. Understand?

S: Yeah.

7. T: Great. Let's try. Ok, this time. It's your turn, Class Five. Who likes to?

[No one responded]

Class Five, no one? [The teacher asked again.]

Gx1: Yes. [A girl from class 6 said happily, she meant no one from Class Five will be volunteer.]

8. T: Class Five, no one?

Gs: Yes, no one. [Several girls respond ironically]

9. T: So you are going to lose, really?

Kang Xiao: No. [Kang Xiao from Class Five said no to fight back and then raised her hand.]

10. T: Ok, Kang Xiao? So you must raise your hand, you must raise your hand, otherwise, you'll lose. Ok, go on.

[Kang Xiao started to recite]

11. T: Ok, good. Class Six? Yah, please Zhou Ming.

[A girl who sat next to Zhou Ming raised her hand as well. But the teacher called Zhou Ming immediately when she saw him raising his hand. The students clapped for Zhou Ming after he finishing reciting.]

12. T: Yeah, good. Really good! Ok, how about Class Five? Class Five? No one? Gx1: Yes. [Gx1 said again happily]

13. T: Class Five. No one! Gx1: Yes. [Gx1 said again firmly]

Bx1: No, of course.

[A boy from Class Five claimed that they had students to recite. However, he did not raise his hand, rather he grasped the hand of a girl next to him. The girl smiled and did not refuse.]

14. T: Really? Ok, Qu Xiaoyan.

[Qu started to recite the text]

15. T: Ok, good. Now Class Six?

[The teacher saw a girl raise her hand, but she did not call her immediately as if she wanted to wait for more students to raise their hand. B2 raised his hand.]

16. T: Ok, Yang Mingliang.

[The teacher was quite surprised to see the boy raising his hand since he was one of the boys whom the teacher poked to wake them up) and called his name happily without thinking. The girl who raised her hand was disappointed] 
[Yang thanked his classmates' support by putting his two hands together to make a traditional Chinese 'thank you' gesture. Then he started to recite. The teacher listened quite carefully. The students were excited. Several girls cheered for him after he finished.]

Gs: Wonderful!

17. T: Ok, great. Yang. You really, really surprise me. Now, who else can, Class Five. Zhang Jie?

The episode occurred in the first lecture of the day, which started quite early in the morning--8: 20 am. Before that the students had to come to school at 6:30 to have 40 minutes of self-study, so some of them were sleepy when the two girls were reciting. The teacher then initiated a competitive activity (T 6). Her intention as she told me afterwards was to create a more intense atmosphere so that those sleepy students would try to concentrate on the class. Her strategies seemed to work well since even she herself was surprised to see the two boy volunteers raise their hands ( $\mathrm{T} 11$ and 16). One of them felt sleepy before the teacher initiated the competition. Another boy, who did not raise his hand, suggested in a loud voice that there were certainly volunteers from his class in order to fight back Gx1 (T 13), who annoyed him by responding to the teacher again and again that there were no volunteers from the boy's class. And the boy raised the hand of Qu Xiaoyan (a girl who sat next to him (T 13).

The intense atmosphere in the class showed that after Kang Xiao asked for her turn; the students were excited by the competition. Zhou Ming in class 6 responded to the competition immediately without hesitation, which gained him the round of warm applause. The activity might not only have aroused the boy's interest, would say that the girls showed their interest as well. But the significance I found in this extract is that the boys tended to be more active than they usually were.

2. Relevant Interesting Points of the Text Presented by the Teacher

The boys seemed to take less interest in the teacher's presentation in the class. But they did not always behave like this. If what the teacher presented was interesting to them, they would give their attention accordingly.

Extract 4:

1. T: Meteorite Man, right? And so we can say he is very, very crazy about rocks. Now besides that, he had only piece of moon rock. Another piece come from Mars. Here do you know Mars. Which planet? Which planet? Do you know this one? Mars. So, it's what? The symbol, the symbol of war. It calls the War God. In fact, what is it? It is Mars. What is the other name for Mars? The star of War God, right?

Shen (B): Why? Why?

[He raised his head and asked why eagerly.]

Shen (a boy) sat in the corner of the first row, which was just beside where I sat. He was drawing a picture of a robot on his book when the teacher was talking. But when the teacher said that Mars was the symbol of war, he suddenly stopped drawing, looked up and asked why twice, suggesting a keen interest in his question. The teacher explained the reason. The boy was satisfied with her answer, nodded and looked down again, circled the words "The Mars" on his book, and noted in Chinese the other name of Mars and the reason for that. It was a mystery whether he learnt anything in the class, except the other name of Mars. But if the teacher had not mentioned that interesting point that Mars still had another name, the boy's attention would still have been focusing on drawing his picture. The presentation of an interesting point relevant to the text and to the boy himself functioned well to get the boys' attention here.

\section{DISCUSSION}

I will discuss some implications of the findings. In terms of differential teacher treatment by gender, the teacher tended to solicit more to girls. I talked with her before I did the classroom observation. She told me at that time that she felt the girls in the class were more supportive to her and got better results. And the impression, the boys gave her was that they were lazy, naughty and less academic than girls in general. As I stated before, she did not nominate individual students very often since the time was too limited for her to teach the students all the knowledge required in one lecture. Her impression of the girls and the time-limitation in the class might be one of the reasons that she nominated girls often, when she needed individuals to give her answer, so that she could get hope to receive a correct answer in a short time.

But we can see that the percentage of positive feedback of the boys (as compared with the whole feedback they got) was higher than for the girls. The teacher had lower expectation for the boys. If boys' performance were better than she expected, she would gave them more positive feedback. And the higher expectation for the girls sometimes would make the teacher give negative feedback. With regard to students talk, the girls called out more often than boys. (It is different form what Trafford \&Clarke found that boys' contributions dominate regardless of whether the discussion concerns school subject content, etc.) I knew from the teacher and from the test results that the academic results of the girls were higher than the boys. I wondered whether because of their low academic achievement in the English texts, some of the students (especially the boys) were not confident enough to be active in the class. However, when I examined three examination results of the class, I found that two boys in the class got quite high marks in all the three exams, even though they were very quiet in class. They listened to the teacher carefully, but if the teacher did not nominate them to answer a question, they seldom opened their mouths to answer the teacher's open questions. "They are quiet students," the teacher told me. 
One boy liked to respond to the teacher if he kept awake (He quite easily felt sleepy during the class), but his academic scores were always below average (he was the one who liked to ask non-academic questions to tease the teacher.) One girl made an impression on me since she always used a loud voice to answer the teacher's question and was actually an active member of the class. She seemed like an out-going girl from the way she talked. However, her academic results were not especially high either. From these examples, I concluded that academic achievement may not be directly related to active academic classroom performance

Another point that might provide a reason why the observed class was relatively quiet As I introduced, the students were all those who failed to enter the best quality schools in the city and this senior high school they had entered required considerably lower entrance marks. That is to say, their academic achievement was quite low before they entered the school. For many of them it would not be possible to have a chance to enter university in the future. For them, the aim is to get the certificate of senior high school or enter a college. The students themselves did not have high motivation to study hard since they knew the fact quite well that they had a lower chance to enter universities. In China, the common belief is that if you fail to enter university, it is unlikely that you will have a promising future.

It was only a small-scale case study. The results may not be able to generalize to other classrooms in other social contexts. They may not even be able to generalize to other Chinese classrooms. But this case may have things in common with other cases. So the findings might shed lights on further studies conducted in china.

\section{CONCLUSION}

My data suggest that general classroom climate may play an important role in reinforcing sex differences in achievement attitudes, beliefs, and performance. Certain kinds of educational environments may facilitate boys' achievement while either dampening or having little positive effect on girls' achievement. Relying on public recitation and student volunteers emerged as two such environmental characteristics in the senior high school study. Competitive goal structures and coeducation are two other characteristics that have been suggested as having similar effects (Eccles, 1984).

The remedy for such differential effects is not clear. Should we educate boys and girls differently so that each experience the educational environment best suited for his or her needs? Probably not, especially some variations within sex make identification of such ideal environments for each sex possible. Instead, educators at all levels need to be aware of the fact that children may respond to similar educational experiences in different ways. Then we can work toward a balance between providing both boys and girls with all types of educational experiences and helping both boys and girls acquire the skills necessary to benefit maximally from various types of learning environment.

Last, as far as Learning guidance concerned, it is structured in two general ways: through solicits or questioning and through feedback. Both of these represent structure. Questioning provides opportunities and variations for thinking about new concepts. Feedback fine tunes ideas in both areas. Although learning to ask questions and participating in questioning is important in language learning, such factors may not be the only variables that may have causal relationships for explaining observed differences in language learning participation. Careful study of the internal, external and social influences, as well as further scrutiny into the quality and subtle nature of verbal interactions and the structure of the learning guidance should be undertaken if gender-related differences in language learning class to be fully understood.

\section{REFERENCES}

[1] Becker, J. (1981). Differential Treatment of Males and Females in Mathematics Classes. Journal of Research in Mathematics Education. 12, 40-53

[2] Clark, A \&Trafford. (1995). Boys into Modern Languages: an Investigation in Attitudes and Performance Between Boys and Girls in Modern Languages. Gender and Education. 7, 315-325

[3] Eccles, J. (1984). Sex Differences in Mathematics Participation. Women in Science. M. Steinkamp \& M. Maehr.(eds) Greenwich, CT: JAI Press,43-70

[4] Good, T, Sikes, N \&Brophy, J. (1973). Effects of Teacher Sex and Student Sex on Classroom Interaction. Journal of Educational Psychology. 5, 30-37

[5] Howe, C. (2002). Gender \& Classroom Interaction: A Research Review. the Scottish Council for Research in Education Press, Scotland.

[6] Rai, S. (1994). Modernisation and Gender: Education and Employment in Post-Mao China. Gender and Education. 6, 119-129

[7] Parson, J., et al. (1980). What teachers Believe-what children achieve. Elementary School Journal. 6, 15-17

[8] Stallings, J. (1979). Factors Influencing Women's Decisions to Enroll in Advanced Mathematics Courses: Executive Summary. Menlo Park.

[9] Sunderland, J. (1996). Sex Bias in Education. London: Blackwell.

Wenhua Hu was born in Dalian, Liaoning Province, China in 1977. She received her M.A degree in applied linguistics from Dalian Institute of Foreign Languages, China in 2004. 
She is currently a PH.D candidate in Dalian University of Technology and a lecturer in the school of Foreign languages, Dalian University of Technology, Liaoning, China. Her research interests include Applied Linguistics, Sociolinguistics \& Philosophy of Language. 